\title{
Effect of ATP on the Rate of the Protoplasmic Streaming in Nitella
}

\author{
by Tadashi SANDAN* and Takao SomurA*
}

山段 忠*・宗村隆生*：フラスモの原形質流動速度におよぼす ATP の影響

Received February 27, 1959

Goldacre and Lorch $(1950)^{1)}$ demonstrated that the flow of endoplasm in Amoeba. discoides occurred in distal direction from the site of 1-3\% ATP injection. Kamiya et al. $(1957)^{2)}$ reported that ATP $\left(2 \times 10^{-3} \mathrm{M}\right)$ admitted from without markedly increased the motive force of the protoplasmic streaming in the plasmodium of Physarum polycephalum and that this effect manifested itself several minutes after the reagent was added and continued several ten minutes after the reagent was removed. Furthermore, using adenylic acid (AMP) from both muscle and yeast, Kamiya et al. could not observe any effect whatsoever comparable to that of ATP. Hatano and Takeuchi $(1959)^{3)}$ showed the existence of ATP in the plasmodium of Physarum polycephalum at the concentration of $0.4 \times 10^{-3} \mathrm{M}$. These experiments favor the assumption that ATP may serve as the direct energy source for the protoplasmic streaming just as it is for muscle contraction and other energy requiring physiological processes.

The effect of ATP on the protoplasmic streaming in plant cells which are equipped with cell wall, or dermatoplasts, has been studied so far but little except that on the protoplasmic motion in the stalk cell of Acetabularia (Takata, 1958) ${ }^{4}$. It is the purpose of the present experiment to investigate the effect of ATP upon the velocity of the protoplasmic rotation in the cell of Characeae.

\section{Material and Method}

From Nitella flexilis, the third internodal cell (ca. $2.5 \mathrm{~cm} . \times$ ca. $400 \mu)$ from the apex was isolated by means of a small scissors and used as the material. Thus isolated cells were kept in distilled water for more than 15 hours prior to the experiment so as to let the cells recover from harm possibly induced by the cutting of their adjacent cells. The experiments were carried out using a glass vessel as shown in Fig. 1. An internodal cell to be investigated was mounted in a definite medium in the concavity (C) which was subsequently sealed with a cover-glass (G). The temperature of the concavity was maintained nearly constant by a continuous flow

* Biological Institute, Kyoto Liberal Arts University, Fukakusa, Kyoto, Japan. 京都学芸 大学生物学教室 
of tap water $\left(22.6 \pm 0.05^{\circ} \mathrm{C}\right.$.) through the tubing $(\mathrm{T})$ enveloping the concavity. The whole vessel was set on the stage of a microscope, and the rate of protoplasmic streaming was determined as the rate of flow of small particles in protoplasm by means of an ocular micrometer and a stopwatch. At first, the rate of protoplasmic flow in a cell placed in a Sörensen's phosphate buffer solution ( $\mathrm{pH} 6.6, \mathrm{M} / 100$ ) was estimated. This control measurement was continued for 20 minutes. Then, the medium was replaced with an ATP solution which was made by dissolving a certain amount of ATP (Na-salt)* into the buffer solution. After the effect of ATP was

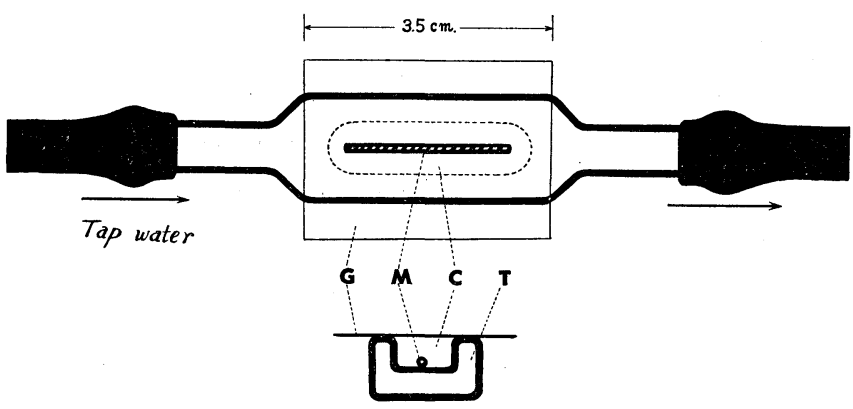

Fig. 1. Glass vessel for the determination of the rate of protoplasmic streaming at constant temperature.

$\mathrm{C}$ : concavity, G: glass cover,

$\mathrm{M}$ : material, $\mathrm{T}$ : tubing for tap water flow. investigated for 70 minutes, the medium was again replaced with the plain buffer solution and the reversibility of the rate of streaming was observed. The effect of AMP (yeast adenylic acid)** at various concentrations on the protoplasmic streaming in the Nitella cell was also examined in a way similar to that mentioned above.

\section{Results and Discussion}

Changes in rate of the protoplasmic streaming caused by the addition of ATP at various concentrations are shown in Figs. 2-6. In these figures, the ordinates represent the rate of flow in microns per second, and the abscissas time in minutes; the time of the medium replacement is indicated with arrows.

As seen in these figures, the rate of flow was kept almost constant in the cells placed in the plain phosphate buffer solution and a temporary decrease in the rate of the streaming or even a momentary stoppage of streaming resulted from the addition of ATP. These changes in the rate of the streaming may be partly due to the possible mechanical shock caused by the replacement of the medium.

In the case of $5 \times 10^{-4} \mathrm{M}$ ATP (Fig. 3), the rate of flow dropped to $6 / 7$ of the control as soon as the ATP solution was substituted for the plain buffer solution. In about 15 minutes, however, the flow did recover from this temporary retardation and further speeded up for a while, the acceleration being $6 \%$ of the control. This acceleration lasted about 40 minutes before the rate came back again to the control level.

* ATP (Na-salt) manufactured by 'Zellstofffabrik Waldhof', Germany.

** AMP manufactured by the Tokyo Chemical Industry Co., Ltd. 
The maximum stimulating effect of ATP was found at $1 \times 10^{-3} \mathrm{M}$ (Fig. 4); the rate of streaming was promoted by $15 \%$ of the control. This acceleration was manifested with a time-lag of about 15 minutes and the accelerated level was maintained unchanged for more than 50 minutes. As ATP was removed, the rate of flow dropped to the initial control level within 10 minutes.

ATP at concentrations below $1 \times 10^{-4} \mathrm{M}$ could not affect the rate of flow. On the other hand, $1 \times 10^{-2} \mathrm{M}$ ATP slowed down gradually the streaming until it completely stopped within 70 minutes. The flow did not recover from this complete suspension even when ATP was removed. The streaming was completely and permanently stopped as soon as ATP at above $1 \times 10^{-2} \mathrm{M}$ was applied.

AMP $\left(<1 \times 10^{-3} \mathrm{M}\right) \quad$ was found to cause little effect on the protoplasmic streaming. In Figs. 7 and 8 is illustrated effect of AMP added at the concentrations of $5 \times 10^{-4} \mathrm{M}$ and $1 \times 10^{-3} \mathrm{M}$, the concentrations at which ATP accelerated the streaming. By addition of AMP $\left(>1 \times 10^{-3} \mathrm{M}\right)$, the streaming was always retarded.

Recently, Takata $(1958)^{4)}$

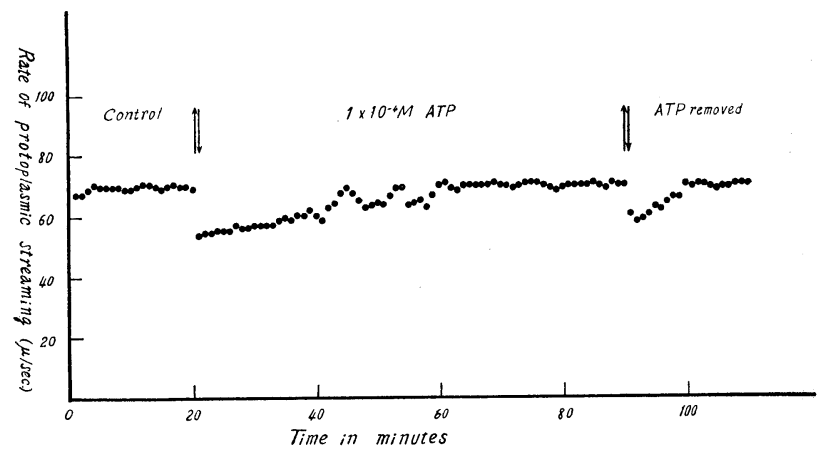

Fig. 2.

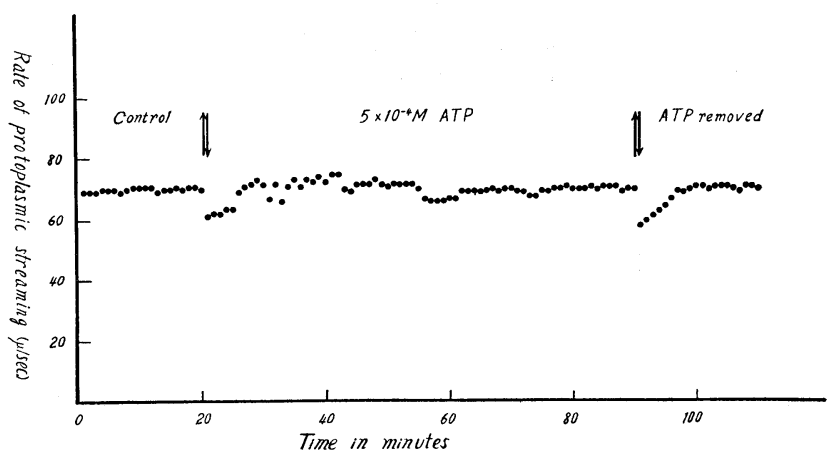

Fig. 3.

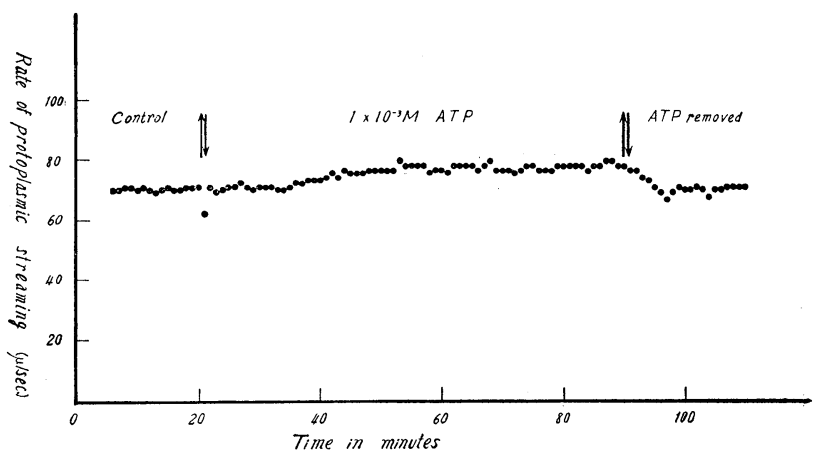

Fig. 4.

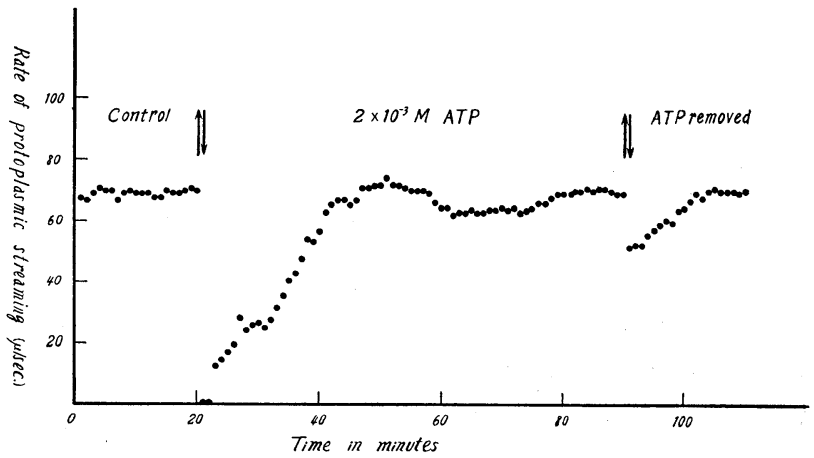

Fig. 5. 


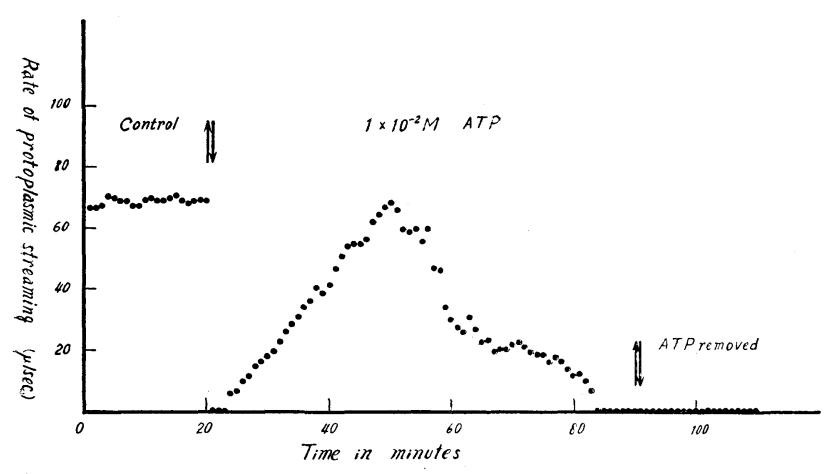

Fig. 6.

Figs. 2-6. The effect of ATP on the rate of protoplasmic streaming. observed that $5 \times 10^{-4} \mathrm{M}$ ATP strongly increased the velocity of the protoplasmic streaming in the stalk cell of Acetabularia calyculus. But this promotion lasted only for a brief period of time. In the present work, the rate of protoplasmic rotation in the internodal cell of Nitella was found to be definitely accelerated, if the acceleration is not conspicuous in amount,

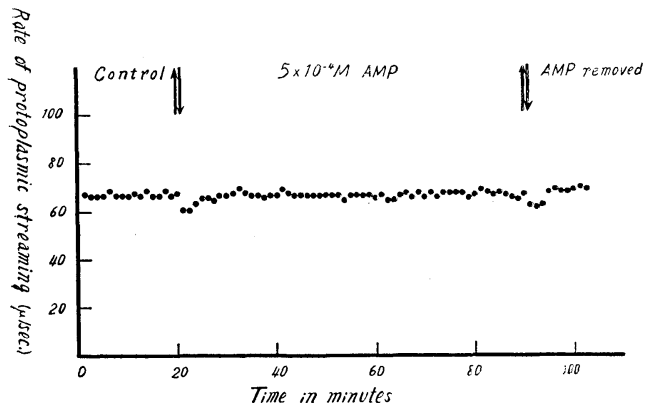

Fig. 7.

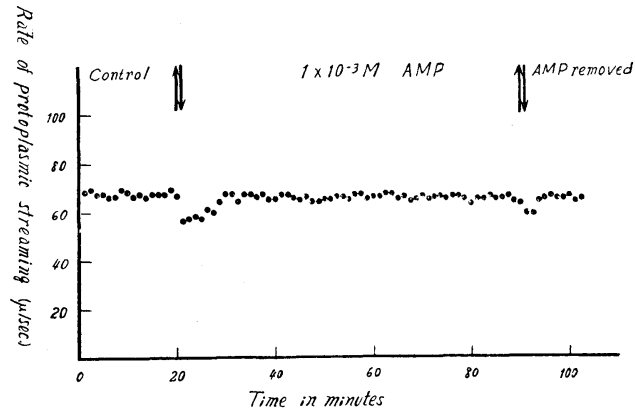

Fig. 8.

Figs. 7-8. The effect of AMP on the rate of protoplasmic streaming.

by the application of ATP at appropriate concentrations. Especially, $1 \times 10^{-3} \mathrm{M}$ ATP increased the velocity of streaming by $15 \%$ for more than 50 minutes. AMP gave no discernible effect of acceleration on the rate of the flow. The results of Takata's and the present experiments appear to suggest a high possibility that ATP may also play a major role in the mechanism of the protoplasmic motion in the cells of green plants.

\section{Summary}

The protoplasmic streaming in the internodal cell of Nitella flexilis was found to be slightly accelerated by the addition of ATP in adequate concentrations. Thus, in the most remarkable case, $1 \times 10^{-3} \mathrm{M}$ ATP increased the rate of the streaming by 15\% with a time-lag of 15 minutes. The accelerated rate was maintained for more than 50 minutes. With the removal of ATP, the rate went down within 10 minutes to the initial low level. AMP gave no discernible effect of acceleration on the rate of streaming in the cell. 
The authors wish to express their most cordial thanks to Prof. N. Kamiya of Osaka University for his kind direction and helpful criticism throughout this work.

\section{References}

1) Goldacre, R. J. and Lorch, I. L., Nature $166: 497$ (1950). 2) Kamiya, N., Nakajima, H. and Abe, S., Protoplasma 48: 94 (1957). 3) Hatano, S. and Takeuchi, I., Protoplasma (in press). 4) Takata, M., Kagaku (Japan) $28: 142$ (1958).

摘

要

フラモス節間細胞の原形賢流動速度は適当濃度のATP 処理によって促進される。もっともいちじるしい 効果は $1 \times 10^{-3} \mathrm{M}$ ATP でみられ，ての場合流動速度は標準值の $15 \%$ 程度高められる。その促進効果は ATP 添加後約 15 分であらわれ, 50 分以上続くが, ATP 除去によって 10 分以内に失われる。

AMP に関しては,いかなる濃度でもATP でみられるようなあきらかな促進効果はみとめられない。 